\title{
Using plasma acute-phase protein concentrations to interpret nutritional biomarkers in apparently healthy HIV-1-seropositive Kenyan adults
}

\author{
David I. Thurnham ${ }^{1}$, Anne S. W. Mburu ${ }^{2}$, David L. Mwaniki ${ }^{2}$, Erastus M. Muniu ${ }^{2}$, Fred Alumasa ${ }^{2}$ \\ and Arjan de $\mathrm{Wagt}^{3}$ \\ ${ }^{1}$ Northern Ireland Centre for Food \& Health, Cromore Road, University of Ulster, Coleraine BT52 1SA, UK \\ ${ }^{2}$ Kenya Medical Research Institute, Centre for Public Health Research, Nairobi, Kenya \\ ${ }^{3}$ HIV/AIDS Section, UNICEF NYHQ, 3 United Nations Plaza, New York, NY 100717, USA
}

(Received 9 March 2007 - Revised 17 September 2007 - Accepted 31 October 2007 - First published online 4 January 2008)

\begin{abstract}
Inflammation influences the assessment of nutritional status. For example, inflammation reduces plasma retinol concentrations and vitamin A deficiency is overestimated. Conversely inflammation increases plasma ferritin concentrations and Fe deficiency is underestimated. Blood samples were obtained from 163 free-living HIV-1-infected adults, not on continuous medication, anti-retroviral drugs or micronutrients, not unwell and who had not reached WHO stage IV of HIV/AIDS. We used four markers of inflammation, C-reactive protein (CRP), $\alpha 1$-acid glycoprotein (AGP), $\alpha 1$-antichymotrypsin and erythrocyte sedimentation rate but mainly CRP and AGP were used to separate the subjects into four groups: 'healthy' where both CRP and AGP were normal; 'incubation phase' where CRP was elevated; 'early convalescence' where AGP and CRP were elevated and 'late convalescence' where only AGP was elevated. Correction factors were calculated to remove the influence of inflammation from each biomarker and group where inflammation was present and the data are shown before and after recalculation. The correction increased median plasma retinol concentrations of the whole group from 1.16 to $1.33 \mu \mathrm{mol} / \mathrm{l}$, comparable with values (mean $1.29 \mu \mathrm{mol} / \mathrm{l}$ ) in HIV-negative Kenyan women. Median ferritin concentrations fell by about $50 \%$ in both sexes and the number of women with plasma ferritin concentrations $\leq 12 \mu \mathrm{g} / \mathrm{l}$ increased from eleven to twenty. The correction also increased plasma carotenoids and $\mathrm{Hb}$ but not $\alpha$-tocopherol concentrations. We suggest that the method described to remove the influence of inflammation from nutritional biomarkers should be generally applicable in apparently healthy people and prevents discarding valuable data because of mild inflammation. The method does now need to be tested in other populations.
\end{abstract}

Vitamin A status: Ferritin: Carotenoids: Acute-phase proteins: HIV-1

The plasma concentrations of several important nutritional biomarkers are influenced by inflammation ${ }^{(1)}$ including retinol $^{(2,3)}, \mathrm{Fe}^{(4)}$, ferritin ${ }^{(5)}, \mathrm{Zn}^{(4)}$, carotenoids ${ }^{(3,6,7)}$, selenium ${ }^{(8)}$, pyridoxal phosphate ${ }^{(9)}$ and vitamin $\mathrm{C}^{(1)}$. Markers of inflammation also show clear patterns of behaviour such that increases in C-reactive protein (CRP) occur in the first $6 \mathrm{~h}$ following infection and show maximum concentrations in $48 \mathrm{~h}^{(10,11)}$ but fall rapidly with the disappearance of clinical disease $^{(12)}$ while other acute-phase proteins (APP) such as $\alpha 1$-acid glycoprotein (AGP) are slower to rise but remain elevated for much longer ${ }^{(10,13)}$. These differences in APP response enabled us to use different combinations of elevated APP in a meta-analysis on fifteen studies of apparentlyhealthy persons to provide a method of adjusting plasma retinol to remove the effects of inflammation ${ }^{(14)}$

Identifying sub-clinical inflammation in apparently-healthy persons with HIV is also important for nutritional intervention studies. It was recently shown that HIV-1-seropositive $(\mathrm{HIV}+)$ women with elevated CRP and AGP showed no increase in serum retinol concentrations following a randomised vitamin A supplementation trial. In contrast serum concentrations increased significantly $(P=0.02)$ in women with no raised $\mathrm{APP}^{(15)}$.

The objective of this paper was to use the methods developed earlier to correct plasma retinol concentrations for the influence of inflammation ${ }^{(14)}$ on several other nutritional biomarkers in free-living Kenyan $\mathrm{HIV}+$ male and female adults $^{(16)}$. Some of these results have been briefly reported elsewhere ${ }^{(17)}$

\section{Methods}

Full details on the study are described elsewhere ${ }^{(16)}$. In brief, 180 persons who tested positive for HIV-1 infection on two occasions (INNOTEST ${ }^{\mathrm{TM}}$ HIV-1/HIV-2 antibody test, Innogenetics, Ghent, Belgium) were recruited into the study. Recruitment took place in two peri-urban centres north of Nairobi: 137 individuals were recruited between February 2002 and

Abbreviations: ACT, $\alpha 1$-antichymotrypsin; AGP, $\alpha 1$-acid glycoprotein; APP, acute-phase proteins; CRP, C-reactive protein; ESR, erythrocyte sedimentation rate; HIV+, HIV-1-seropositive; HIV-, HIV-1-seronegative.

* Corresponding author: Professor David I. Thurnham. Current address MRC Human Nutrition Research, Elsie Widdowson Laboratory, Fulbourn Road, Cambridge CBI 9NL, UK, fax + 442870324965 , email di.thurnham@ulster.ac.uk 
January 2003 at Nakuru and forty-three others between October 2002 and March 2003 at Nanyuki. Both centres are in the upper reaches of the Rift Valley Province found within the Central and Midwest Highlands of Kenya. The persons were living in their own homes and had not reached stage IV of clinical AIDS by WHO classification. Eligibility criteria for inclusion in the study were HIV positivity, non-pregnant and non-lactating if female, presenting to various HIV-support organisations or a local referral or medical facility and aged between 18 and 35 years. If persons were positive for TB, they had to have received at least 2 months' anti-TB treatment to be eligible for recruitment. Persons were additionally excluded if a concurrent illness was present which required ongoing medical intervention, presented with clinical AIDS (WHO stage IV), were already consuming micronutrients, receiving anti-retroviral therapy or any other drugs, were of no fixed address or were not willing to participate. Once recruited, the subjects were allocated to receive either a food supplement or the food plus additional micronutrients but the follow-up results will be reported elsewhere.

A blood sample was taken from persons who felt well. Persons who felt unwell were given an alternative date for blood sampling. A total of 174 persons provided a blood sample before any supplements were received. Insufficient blood or laboratory problems prevented some analyses and the results for 163 samples (men, $n 56$ and women, $n$ 107) are presented in this paper. Ethical approval for the study was obtained from the Scientific Steering Committee of the Kenya Medical Research Institute, the National Ethical Review Board and the Contracts Review Committee of UNICEF East and Southern Africa Regional Office.

\section{Biochemical methods}

$\mathrm{Hb}$ and erythrocyte sedimentation rate (ESR) were measured on freshly collected blood in local laboratories. $\mathrm{Hb}$ was determined by the cyanmethaemoglobin method on $200 \mu \mathrm{l}$ whole blood. ESR was measured in a $4: 1$ trisodium citrate ( $109 \mathrm{mmol} / \mathrm{l})$-blood mixture where a $20 \mathrm{~cm} \times 2.55 \mathrm{~mm}$ column of diluted blood was allowed to stand for $60 \mathrm{~min}$ and the column of packed red cells measured to the nearest $\mathrm{mm}$. CD4 and CD8 T-lymphocyte subset counts were obtained on anticoagulated whole blood (EDTA vacutainers, Becton Dickinson) within $24 \mathrm{~h}$ of collection using a FACSCount ${ }^{\mathrm{TM}}$ System (Becton Dickinson) at the Centre for Biotechnology, Development and Research, KEMRI, Nairobi. The FACSCount $^{\mathrm{TM}}$ System was standardised daily with manufacturer's standards.

Plasma was prepared in the local laboratories and shipped frozen to Nairobi where it was stored at $-20^{\circ} \mathrm{C}$ for up to 15 months prior to analysis. Plasma ferritin concentrations were measured at the Biochemistry Department, Kenyatta National Hospital, Nairobi. Ferritin was measured by an automated one-step sandwich enzyme immunoassay with final fluorescence detection (Mini Vidas, BioMerieux, France). Kits provided manufacturers' standards and controls and a precision between 4 and $7 \%$ was obtained.

At the end of the study, plasma was sent in dry ice to the laboratories of Professor H. Friis (Aalburg University, Denmark) to measure viral load by the method of Krarup et al. ${ }^{(18)}$. The quantification was made in genomic equivalents per $\mathrm{ml}$ blood $(\mathrm{geq} / \mathrm{ml})$. The remaining measurements were done at the laboratories of the Northern Ireland Centre for Food and Health, Coleraine. Samples were shipped in dry ice to Northern Ireland and stored at $-70^{\circ} \mathrm{C}$ for up to a further two months before analysis. Retinol, the carotenoids and tocopherols were measured on $100 \mu \mathrm{l}$ plasma using liquid chromatography ${ }^{(19,20)}$. $\alpha 1$-Antichymotrypsin (ACT), AGP and CRP were measured using DAKO reagents (Dako Ltd, Denmark) using a Hitachi 912 Clinical Analyzer (Roche Diagnostics Ltd, Welwyn, UK). Analysis required $<100 \mu l$ for each analysis and plasma was diluted automatically prior to analysis. Inter-assay precision of the liquid chromatography varied between 5 and $10 \%$ and was $\leq 5 \%$ for each of the APP. Limits of detection for the APP were about $0.2 \mathrm{~g} / \mathrm{l}$ for ACT and AGP and about $0.1 \mathrm{mg} / \mathrm{l}$ for CRP.

\section{Data handling}

Much of the data was skewed so comparison of groups or between sexes was done on log-transformed data except where indicated. In the Tables, all data are shown as medians and 25 th and 75 th quartiles.

As the purpose of the paper was to examine the influence of the APP on the nutritional markers, the data were grouped using the following criteria. The healthiest of the recruits (or reference group) were characterised as having normal ACT $(\leq 0.4 \mathrm{~g} / \mathrm{l})$, normal AGP $(\leq 1.0 \mathrm{~g} / \mathrm{l})$ and normal CRP $(\leq 5 \mathrm{mg} / \mathrm{l})$ activity. The second group is described as being in the 'incubation' phase or early stage of infection when CRP or ACT is rising but AGP is still within the normal range. In early convalescence (stage 3 ), elevated CRP (or ACT) and an elevated AGP occur together but in later convalescence (stage 4) only AGP is elevated. It was noted in grouping the recruits that CRP and AGP were the major determinants. An elevated plasma ACT concentration when CRP was not raised only influenced the position of three individuals. To remove the influence of inflammation from the nutritional biomarkers, correction factors were calculated by dividing the median value of the biomarker for the reference group by the respective median values for groups at stages 2, 3 and 4.

ESR was not used in the above treatment. The ESR reflects a number of changes predominantly in the viscosity of the blood accompanying an infection. Changes in viscosity can be due to changes in the permeability of the vasculature as well as the increase in proteins like fibrinogen. It is therefore less easy to link changes in the ESR to different stages in the infective process.

\section{Role of the funding source}

The study sponsors played no part in the study design, in the collection, analysis and interpretation of data, in the writing of this paper or in our decision to submit for publication.

\section{Results}

The baseline nutritional and inflammatory biomarkers obtained in the Kenyan men and women are shown in Table 1. Differences between the sexes were found for $\mathrm{Hb}$ and ferritin, three of the carotenoids, ESR and ACT, and the proportion 
Table 1. Plasma concentrations of nutritional and inflammatory markers (erythrocyte sedimentation rate (ESR), C-reactive protein (CRP), antichymotrypsin (ACT) and $\alpha 1$-acid glycoprotein (AGP)) and proportions abnormal using conventional cut-off values

(Median values with 25 th and 75 th quartiles)

\begin{tabular}{|c|c|c|c|c|c|c|c|c|}
\hline & & \multicolumn{2}{|c|}{$\begin{array}{l}\text { Concentration ( } n \text { 163; } \\
56 \text { men, } 107 \text { women) }\end{array}$} & \multirow[b]{2}{*}{ Cut-off threshold } & \multirow[b]{2}{*}{ Reference } & \multicolumn{2}{|c|}{$\begin{array}{l}\text { Number outside } \\
\text { the threshold }\end{array}$} & \multirow{2}{*}{$\begin{array}{l}P \text { for difference } \\
\text { between sexes }\end{array}$} \\
\hline & & Median & Quartiles & & & $n$ & $\%$ & \\
\hline \multicolumn{2}{|l|}{ Retinol $(\mu \mathrm{mol} / \mathrm{l})$} & $1 \cdot 16$ & $0.87,1.47$ & $\leq 0.7 \mu \mathrm{mol} / \mathrm{l}$ & Sommer \& Davidson ${ }^{(21)}$ & 32 & 20 & 0.95 \\
\hline \multicolumn{2}{|l|}{ Lutein $(\mu \mathrm{mol} / \mathrm{l})$} & 0.296 & $0.177,0.459$ & NA & & & & 0.17 \\
\hline \multicolumn{2}{|l|}{$\begin{array}{c}\alpha-T o c o p h e r o l \\
(\mu \mathrm{mol} / \mathrm{l})\end{array}$} & $14 \cdot 28$ & $6 \cdot 40,18 \cdot 28$ & $\leq 11 \mu \mathrm{mol} / \mathrm{l}$ & Thurnham et al. ${ }^{(24)}$ & 6 & 4 & 0.12 \\
\hline \multicolumn{2}{|l|}{$\begin{array}{c}\gamma \text {-Tocopherol } \\
(\mu \mathrm{mol} / \mathrm{l})\end{array}$} & 0.57 & $0.43,0.89$ & NA & & - & & 0.44 \\
\hline \multirow[t]{2}{*}{ Ferritin $(\mu \mathrm{g} / \mathrm{l})$} & Men & 488 & 204,1086 & $\leq 12 \mu \mathrm{g} / \mathrm{l}$ & Worwood $^{(23)}$ & 0 & 0 & $<0.001$ \\
\hline & Women & 90 & 31,220 & & & 11 & 10 & \\
\hline \multirow[t]{2}{*}{$\mathrm{Hb}(\mathrm{g} / \mathrm{l})$} & Men & 132 & 117,143 & $\leq 130 \mathrm{~g} / \mathrm{l} \dagger$ & UNICEF et al. ${ }^{(22)}$ & 25 & 44 & $<0.001$ \\
\hline & Women & 116 & 105,124 & $\leq 120 \mathrm{~g} / \mathrm{l}$ & & 63 & 59 & \\
\hline \multirow{2}{*}{$\begin{array}{c}\beta \text {-Carotene } \\
(\mu \mathrm{mol} / \mathrm{l})\end{array}$} & Men & 0.164 & $0.073,0.248$ & $\leq 0.075 \mu \mathrm{mol} / \mathrm{l}$ & Mehendale et al. ${ }^{(39)}$ & 14 & 25 & 0.015 \\
\hline & Women & 0.300 & $0.119,0.438$ & & & 17 & 16 & \\
\hline \multirow[t]{2}{*}{$\begin{array}{c}\alpha-\text { Carotene } \\
(\mu \mathrm{mol} / \mathrm{l})\end{array}$} & Men & 0.044 & $0.02,0.09$ & NA & & & & 0.018 \\
\hline & Women & 0.080 & $0.033,0.130$ & & & & & \\
\hline \multirow[t]{2}{*}{$\begin{array}{l}\text { Lycopene } \\
(\mu \mathrm{mol} / \mathrm{l})\end{array}$} & Men & 0.063 & $0.024,0.130$ & NA & & & & 0.024 \\
\hline & Women & 0.105 & $0.049,0.189$ & & & & & \\
\hline \multirow[t]{2}{*}{$\operatorname{ESR}(\mathrm{mm} / \mathrm{h})$} & Men & 49 & $17 \cdot 5,82$ & $>20 \mathrm{~mm} / \mathrm{h}$ & Dacie \& Lewis ${ }^{(40)}$ & 38 & 68 & 0.001 \\
\hline & Women & 74 & 39,93 & & & 90 & 84 & \\
\hline \multirow[t]{2}{*}{ ACT (g/l) } & Men & 0.35 & $0.27,0.49$ & $>0.4 \mathrm{~g} / \mathrm{l}$ & Thurnham et al. ${ }^{(14)}$ & 24 & 43 & 0.001 \\
\hline & Women & 0.31 & $0.25,0.37$ & & & 22 & 21 & \\
\hline \multirow[t]{2}{*}{ AGP $(g / l)$} & Men & 1.05 & $0.73,1.79$ & $>1.0 \mathrm{~g} / \mathrm{l}$ & Thurnham et al. ${ }^{(14)}$ & 33 & 59 & 0.063 \\
\hline & Women & 0.93 & $0.73,1.29$ & & & 46 & 43 & \\
\hline CRP (mg/l) & All & 4.97 & $0 \cdot 86,17 \cdot 14$ & $>5.0 \mathrm{mg} / \mathrm{l}$ & Thurnham et al. ${ }^{(14)}$ & 81 & 50 & 0.39 \\
\hline
\end{tabular}

NA, cut-off values not available.

*ANOVA of log base10 values except for $\alpha$-tocopherol, $\mathrm{Hb}$ and ACT where the data were not transformed.

†Cut-off to define moderate anaemia.

of abnormal results is shown separately for the sexes for these variables. The median concentration of plasma retinol was $1.16 \mu \mathrm{mol} / 1$ and $20 \%$ of adults had plasma retinol concentrations $\leq 0.7 \mu \mathrm{mol} / \mathrm{l}^{(21)}$. Anaemia ${ }^{(22)}$ was present in $59 \%$ of women and $10 \%$ plasma ferritin concentrations indicated deficient stores of liver $\mathrm{Fe}(\leq 12 \mu \mathrm{g} / \mathrm{l})^{(23)}$. Approximately $44 \%$ of men had anaemia $(\leq 130 \mathrm{~g} / \mathrm{l})$ but there were none with deficient liver Fe stores. The overall concentration of $\alpha$-tocopherol in plasma was low but there were only $4 \%$ (six of 163) with values suggesting a risk of deficiency $(<11.0 \mu \mathrm{mol} / \mathrm{l})^{(24)}$.

Pearson correlation coefficients between the different inflammatory and nutritional biomarkers are shown in Table 2 . Retinol was inversely related with all four acute phase markers but the correlations were only significant with ESR and AGP. In contrast, ferritin (positively) and $\mathrm{Hb}$ (negatively) were significantly correlated with all four acute phase markers. It is noteworthy that ferritin was strongly correlated with the more chronic indicators of inflammation, ACT and AGP. All the carotenoids showed negative relationships with the APP; however, those with ESR were not significant while those with AGP were strongly significant. The tocopherols displayed no relationships. Inter-correlations between the APP were generally strong for ACT, AGP and CRP and less so with ESR. ESR was most strongly correlated with AGP and ACT and especially with $\mathrm{Hb}$.
When the nutritional and other data were split into the four inflammation groups in accordance with the acute phase status defined in the methods, there were significant differences between the groups for all nutrients except retinol $(P=0.09)$,

Table 2. Pearson correlation coefficients for the nutritional and inflammatory biomarkers (erythrocyte sedimentation rate (ESR), C-reactive protein (CRP), $\alpha 1$-antichymotrypsin (ACT) and $\alpha 1$-acid glycoprotein (AGP) (n 163)

\begin{tabular}{|c|c|c|c|c|}
\hline \multirow[b]{2}{*}{ Nutritional biomarkers } & \multicolumn{4}{|c|}{ Inflammatory biomarkers } \\
\hline & ESR & CRP & $\mathrm{ACT}^{*}$ & AGP \\
\hline Retinol $(\mu \mathrm{mol} / \mathrm{l})$ & $-0.167 \dagger$ & -0.038 & -0.060 & $-0.169 \dagger$ \\
\hline Ferritin $(\mu \mathrm{g} / \mathrm{l})$ & $0.170 \dagger$ & $0.303 \ddagger$ & $0.572 \ddagger$ & $0.595 \ddagger$ \\
\hline $\mathrm{Hb}(\mathrm{g} / \mathrm{l})^{\star}$ & $-0.585 \ddagger$ & $-0.270 \ddagger$ & $-0.235 \ddagger$ & $-0.310 \ddagger$ \\
\hline$\beta$-Carotene $(\mu \mathrm{mol} / \mathrm{l})$ & -0.079 & $-0.159 \dagger$ & $-0.190 \dagger$ & $-0.371 \ddagger$ \\
\hline$\alpha$-Carotene $(\mu \mathrm{mol} / \mathrm{l})$ & -0.133 & $-0.154 \dagger$ & $-0.181 \dagger$ & $-0.356 \ddagger$ \\
\hline Lutein $(\mu \mathrm{mol} / \mathrm{l})$ & -0.123 & $-0.179 \dagger$ & -0.115 & $-0.204 \ddagger$ \\
\hline Lycopene $(\mu \mathrm{mol} / \mathrm{l})$ & -0.139 & $-0.194 \dagger$ & $-0.200 \ddagger$ & $-0.306 \ddagger$ \\
\hline$\alpha$-Tocopherol $(\mu \mathrm{mol} / \mathrm{l})^{*}$ & 0.059 & 0.014 & 0.095 & 0.062 \\
\hline$\gamma$-Tocopherol $(\mu \mathrm{mol} / \mathrm{l})$ & 0.049 & -0.033 & -0.033 & 0.008 \\
\hline $\operatorname{CRP}(g / l)$ & $0.184 \dagger$ & - & $0.538 \ddagger$ & $0.566 \ddagger$ \\
\hline ACT $(g / l)^{*}$ & $0.318 \ddagger$ & $0.538 \ddagger$ & - & $0 \cdot 797 \ddagger$ \\
\hline$A G P(g / l)$ & $0.414 \ddagger$ & $0.566 \ddagger$ & $0.797 \ddagger$ & - \\
\hline
\end{tabular}

${ }^{*}$ Correlation coefficients obtained using log base10 values of all variables except those marked.

$\dagger P<0.05$.

$\ddagger P<0.01$. 
Table 3. Concentrations of nutritional markers in different stages of inflammation as defined by the acute-phase proteins (APP)*, antichymotrypsin (ACT), $\alpha 1$-acid glycoprotein (AGP) and C-reactive proteins (CRP)

(Median values with 25th and 75th quartiles)

\begin{tabular}{|c|c|c|c|c|c|c|c|c|c|c|c|c|c|}
\hline & \multicolumn{3}{|c|}{ Normal APP $(n 66)$} & \multicolumn{3}{|c|}{ Incubating ( $n$ 18) } & \multicolumn{3}{|c|}{ Early convalescence $(n 63)$} & \multicolumn{3}{|c|}{ Late convalescence $(n 16)$} & \multirow[b]{2}{*}{ ANOVAT $P$} \\
\hline & Median & Quartiles & $n$ & Median & Quartiles & $n$ & Median & Quartiles & $n$ & Median & Quartiles & $n$ & \\
\hline $\begin{array}{l}\text { Retinolł ( } \mu \mathrm{mol} / \mathrm{l}) \\
\mathrm{CF} \text { (this study) }\end{array}$ & 1.33 & $1.00,1.56$ & & $\begin{array}{l}1.25 \\
1.064\end{array}$ & $0.84,1.54$ & & $\begin{array}{l}1.01 \\
1.317\end{array}$ & $0.61,1.33$ & & $\begin{array}{l}1.10 \\
1.209\end{array}$ & $0.84,1.41$ & & 0.090 \\
\hline $\begin{array}{l}\text { CF\& (from the } \\
\text { previous } \\
\text { meta-analysis) }\end{array}$ & & & & 1.13 & & & 1.24 & & & $1 \cdot 11$ & & & \\
\hline $\begin{array}{l}\text { Ferritin } \neq \|(\mu \mathrm{g} / \mathrm{l}) \\
\text { Men } n 56\end{array}$ & $166^{\mathrm{a}}$ & 94,277 & 19 & $262^{\mathrm{ab}}$ & 99,572 & 4 & $1004^{b}$ & 448,1200 & 28 & $540^{\mathrm{ab}}$ & 187,938 & 5 & $<0.001$ \\
\hline CF & & & & 0.630 & & & 0.165 & & & 0.307 & & & \\
\hline 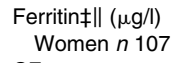 & $41^{\mathrm{a}}$ & 13,150 & 47 & $50^{\mathrm{a}}$ & 20,97 & 14 & $213^{b}$ & 100,386 & 37 & $107^{\mathrm{ab}}$ & 47,208 & 9 & $<0.001$ \\
\hline $\mathrm{CF}$ & & & & 0.820 & & & 0.190 & & & 0.380 & & & \\
\hline $\begin{array}{l}\mathrm{Hb} \|(\mathrm{g} / \mathrm{l}) \\
\quad \operatorname{Men} n 56\end{array}$ & $138^{\mathrm{a}}$ & 132,156 & 19 & $130^{\mathrm{a}}$ & $92,139.5$ & 4 & $123^{b}$ & 109,123 & 28 & $158^{\mathrm{a}}$ & $119 \cdot 5,170$ & 5 & 0.001 \\
\hline $\mathrm{CF}$ & & & & 1.062 & & & 1.122 & & & 0.873 & & & \\
\hline $\begin{array}{l}\mathrm{Hb} \|(\mathrm{g} / \mathrm{l}) \\
\quad \text { Women } n 107\end{array}$ & 120 & 108,132 & 47 & 114 & $94 \cdot 5,19 \cdot 3$ & 14 & 113 & $100 \cdot 5,120$ & 37 & 116 & $100 \cdot 5,132$ & 9 & 0.064 \\
\hline CF & & & & 1.053 & & & 1.062 & & & 1.034 & & & \\
\hline $\begin{array}{l}\beta \text {-Carotene } \neq \\
\quad(\mu \mathrm{mol} / \mathrm{l}) \\
\mathrm{CF}\end{array}$ & $0.320^{\mathrm{a}}$ & $0.175,0.499$ & & $\begin{array}{l}0.323^{\mathrm{ac}} \\
0.991\end{array}$ & $0.181,0.456$ & & $\begin{array}{l}0.141^{b} \\
2.270\end{array}$ & $0.05,0.287$ & & $\begin{array}{l}0.161^{\mathrm{bc}} \\
1.988\end{array}$ & $0.042,0.286$ & & $<0.001$ \\
\hline $\begin{array}{c}\alpha-\text { Carotene } \neq \\
(\mu \mathrm{mol} / /)\end{array}$ & $0 \cdot 103^{\mathrm{a}}$ & $0.044,0.146$ & & $0.086^{\mathrm{ab}}$ & $0.035,0.148$ & & $0.041^{b}$ & $0.012,0.081$ & & $0.035^{\mathrm{b}}$ & $0.013,0.077$ & & $<0.001$ \\
\hline CF & & & & 1.198 & & & 2.512 & & & 2.943 & & & \\
\hline $\begin{array}{l}\text { Lutein‡ }(\mu \mathrm{mol} / \mathrm{l}) \\
\mathrm{CF}\end{array}$ & $0.385^{\mathrm{a}}$ & $0.252,0.519$ & & $\begin{array}{l}0.344^{\mathrm{ab}} \\
1.119\end{array}$ & $0.172,0.468$ & & $\begin{array}{l}0.220^{\mathrm{b}} \\
1.750\end{array}$ & $0.116,0.366$ & & $\begin{array}{l}0.278^{\text {ab }} \\
1.385\end{array}$ & $0.207,0.485$ & & 0.005 \\
\hline $\begin{array}{l}\text { Lycopeneł } \\
(\mu \mathrm{mol} / \mathrm{l})\end{array}$ & $0.124^{a}$ & $0.080,0.217$ & & $0.094^{\mathrm{ab}}$ & $0.046,0.184$ & & $0.059^{b}$ & $0.02,0.114$ & & $0.087^{\mathrm{ab}}$ & $0.044,0.140$ & & 0.001 \\
\hline $\mathrm{CF}$ & & & & 1.319 & & & $2 \cdot 102$ & & & 1.425 & & & \\
\hline $\begin{array}{l}\text { ESR } \neq(\mathrm{mm} / \mathrm{h}) \\
\mathrm{CF}\end{array}$ & $42^{\mathrm{a}}$ & 18,79 & & $\begin{array}{l}64.5^{\mathrm{ab}} \\
0.651\end{array}$ & $22 \cdot 5,91$ & & $\begin{array}{l}80^{\mathrm{b}} \\
0.525\end{array}$ & 54,99 & & $\begin{array}{l}60^{a b} \\
0 \cdot 700\end{array}$ & 21,91 & & $<0.001$ \\
\hline $\begin{array}{c}\alpha-\text { Tocopherol } \\
(\mu \mathrm{mol} / /)\end{array}$ & 14.06 & $9 \cdot 24,18 \cdot 10$ & & $14 \cdot 10$ & $1 \cdot 12,19 \cdot 95$ & & 14.73 & $1 \cdot 80,19 \cdot 2$ & & 13.71 & $7 \cdot 78,16.9$ & & 0.885 \\
\hline $\begin{array}{c}\gamma \text {-Tocopherolł } \\
(\mu \mathrm{mol} / \mathrm{l})\end{array}$ & 0.56 & $0.35,0.89$ & & 0.59 & $0.50,0.79$ & & 0.57 & $0.43,0.92$ & & 0.65 & $0.48,1.05$ & & 0.463 \\
\hline $\begin{array}{l}\mathrm{CD} 4 \text { count } \\
(\text { cells } / \mu l)\end{array}$ & $362^{\mathrm{a}}$ & 270,680 & 27 & $210^{\mathrm{ab}}$ & 76,375 & 7 & $154^{\mathrm{b}}$ & 40,285 & 24 & $168^{\mathrm{ab}}$ & 61,200 & 7 & 0.004 \\
\hline $\begin{array}{l}\text { CD4:CD8 } \\
\text { (group sizes } \\
\text { as above) }\end{array}$ & 0.42 & $0 \cdot 14,0.6^{a}$ & & $0 \cdot 28^{\mathrm{ab}}$ & $0.09,0.31$ & & $0 \cdot 13^{b}$ & $0.07,0.25$ & & $0.11^{b}$ & $0.04,0.17$ & & 0.001 \\
\hline $\begin{array}{c}\text { Viral loadf } \\
\text { (geq/ml) }\end{array}$ & $2350^{\mathrm{a}}$ & 125,32000 & 62 & $5800^{a b}$ & 2500,140000 & 15 & $24000^{b}$ & 2275,207500 & 60 & $69000^{\mathrm{ab}}$ & 880,210000 & 11 & 0.005 \\
\hline
\end{tabular}

$\mathrm{CF}$, correction factor (derived by dividing the reference median value by the median for the respective groups with raised APP; CF were not calculated for $\alpha$ - or $\gamma$-tocopherol as there was no difference between the groups); ESR

erythrocyte sedimentation rate.
*Normal APP were plasma concentrations: ACT $\leq 0.4 \mathrm{~g} / \mathrm{l}, \mathrm{CRP} \leq 5 \mathrm{mg} / \mathrm{l}$ and AGP $\leq 1.0 \mathrm{~g} / \mathrm{l}$. Incubating was defined as concentrations above the cut-offs indicated for ACT or CRP and an AGP concentration $\leq 1.0 \mathrm{~g} / \mathrm{l}$. Early convalescence was defined as elevated AGP and elevated ACT or CRP. Late convalescence was defined as an elevated AGP only.

† ANOVA followed by Scheffé test. a,b Mean values with unlike superscripts indicate significant difference between means of subgroups.

\# Statistics performed on log base10 data.

$\S$ Correction factors from reference Thurnham et al..$^{(14)}$.

The large difference in the numbers of men and women in the sample and in some cases e.g. plasma ferritin, the difference in concentrations between the sexes, necessitated separating the sexes to calculate appropriate CF. 
$\alpha$-tocopherol $(P=0.89)$ and $\gamma$-tocopherol $(P=0.49)$ (Table 3$)$. Furthermore, with the exception of vitamin $\mathrm{E}$, the plasma concentrations of all the nutrient biomarkers showed greatest evidence of abnormalities in the early and late convalescent groups. Correction factors are also shown in Table 3. The factors adjusted median concentrations in each inflammatory group to that of the group with no raised APP, to remove the influence of inflammation. Also shown in Table 3 are plasma viral loads, CD4 T-lymphocyte subset counts and CD4:CD8 ratios as markers of the HIV-1 severity in the specific, acute-phase groups. For all three clinical markers, the poorest results were associated with raised AGP. It should also be noted that median ESR concentrations were abnormally elevated in all groups including the reference group.

Table 4 shows concentrations of nutrient biomarkers after correction. As expected the correction procedure produces median values the same as those shown in the reference column in Table 3. In the case of retinol, the use of both sets of correction factors increased median retinol concentration from 1.16 to 1.33 (this study) and 1.31 (meta-analysis) with virtually the same interquartile range in both cases. The prevalence of plasma retinol concentrations $\leq 0.7 \mu \mathrm{mol} / \mathrm{l}$ fell from 20 to $13 \%$ (this study) or to $16 \%$ (meta-analysis). Correcting plasma ferritin concentrations more than halved the median concentrations of ferritin in both sexes and increased the apparent number of women in the study with Fe-deficient liver stores from eleven to twenty. Corrections to $\mathrm{Hb}$ only slightly reduced the apparent number of people of both sexes with anaemia. There was only one person in each group where $\mathrm{Hb}$ was $<70 \mathrm{~g} / \mathrm{l}$. In the men, this case was removed by the correction but not so in the women. There are no universally recognised cut-off values for the carotenoids but it should be noted that corrections increased median concentrations.

Table 5 shows the corrected retinol and ferritin results for the HIV+ subjects compared with data from HIV seronegative $(\mathrm{HIV}-)$ persons in the Kenyan National Nutrition Survey ${ }^{(25)}$ and in a report by Baeten et al. ${ }^{(26)}$ The corrected median plasma retinol was almost identical to that reported for HIV - Kenyan women who had no raised inflammatory proteins and the proportion of low values of plasma retinol concentrations in the corrected data was lower than that found in the Kenyan Survey. ${ }^{(25)}$ Corrections to plasma ferritin concentrations in the HIV+ men and women produced values more comparable with those of the HIV - adults in the community.

Food frequency data were collected (not shown) but there was no association between any of the foods and the nutritional biomarkers. Meals would be taken frequently with 'ugali' which is a thick porridge prepared from whole ground white maize. Most subjects reported eating carrots, spinach and kale frequently and these would be chopped and fried with tomatoes, oil and meat when available. The frequent consumption of vitamin $\mathrm{A}$ and $\mathrm{Fe}$-containing food is in agreement with the high carotenoid and ferritin values in the reference group.

\section{Discussion}

In recent years workers have become increasingly aware that inflammation can alter nutritional biomarkers. To detect inflammation CRP has been used and when elevated values are found, data are usually excluded. Often a relatively high cut-off is used (about $10 \mathrm{mg} / \mathrm{l}$ ) and the procedure has two disadvantages: potentially valuable data are lost and some influence of inflammation may still remain because subjects with CRP values between 5 and $10 \mathrm{mg} / \mathrm{l}$ are still included. Furthermore, workers rarely measure AGP, so any influence of chronic inflammation on the data is ignored. Alternatively, regression analyses using the change in APP to predict the change in retinol ${ }^{(27)}$ or ferritin ${ }^{(28)}$ have also been unsuccessfully used as individual APP do not reflect exactly the behaviour of nutritional biomarkers throughout the period of inflammation especially in apparently healthy people. In the latter correlations between APP and nutritional biomarkers are poor and changes in APP explain very little of the variance in the nutritional biomarkers ${ }^{(28)}$.

Table 4. Concentrations of nutritional biomarkers after correction* for the presence of sub-clinical inflammation

\begin{tabular}{|c|c|c|c|c|c|c|c|c|c|}
\hline \multirow{3}{*}{$\begin{array}{l}\text { Nutritional biomarker } \\
\text { (Total } n 163 \text { ) }\end{array}$} & & \multicolumn{4}{|c|}{ Uncorrected data } & \multicolumn{4}{|c|}{ Corrected data } \\
\hline & & \multirow[b]{2}{*}{ Median } & \multirow[b]{2}{*}{ Quartiles } & \multicolumn{2}{|c|}{$\begin{array}{c}\text { Abnormal } \\
\text { results } †\end{array}$} & \multirow[b]{2}{*}{ Median } & \multirow[b]{2}{*}{ Quartiles } & \multicolumn{2}{|c|}{$\begin{array}{c}\text { Abnormal } \\
\text { results }\end{array}$} \\
\hline & & & & $n$ & $\%$ & & & $n$ & $\%$ \\
\hline Retinol $(\mu \mathrm{mol} / \mathrm{l})$ & & $1 \cdot 16$ & $0.87,1.47$ & 32 & 20 & 1.33 & $0.94,1.63$ & 22 & 13 \\
\hline Lutein $(\mu \mathrm{mol} / \mathrm{l})$ & & 0.296 & $0.177,0.459$ & \multicolumn{2}{|c|}{ NA } & 0.386 & $0.240,0.563$ & \multicolumn{2}{|c|}{ NA } \\
\hline \multirow[t]{2}{*}{ Ferritin $(\mu \mathrm{g} / \mathrm{l})$} & Men & 488 & 204,1086 & \multicolumn{2}{|c|}{0} & 166 & 82,198 & \multicolumn{2}{|c|}{0} \\
\hline & Women & 90 & 32,220 & 11 & 10 & 41 & 17,105 & 20 & 19 \\
\hline \multirow[t]{2}{*}{$\mathrm{Hb}(\mathrm{g} / \mathrm{l})$} & Men & 132 & 117,143 & 25 & 44 & $138 \S$ & 126,150 & 18 & 32 \\
\hline & Women & 116 & 105,124 & 63 & 59 & $120 \S$ & 107,130 & 53 & 50 \\
\hline \multirow{2}{*}{$\begin{array}{c}\beta \text {-Carotene } \\
(\mu \mathrm{mol} / \mathrm{l})\end{array}$} & Men & $0 \cdot 164$ & $0.073,0.248$ & 14 & 25 & $0 \cdot 218$ & $0 \cdot 124,0.387$ & 10 & 18 \\
\hline & Women & 0.300 & $0.199,0.438$ & 17 & 16 & 0.381 & $0.207,0.589$ & 13 & 12 \\
\hline
\end{tabular}

* Corrected data was obtained by multiplying the uncorrected values by the respective correction factor (CF) values (see Table 3) for the appropriate acute-phase-protein group in which they were situated.

†Thresholds of abnormality are listed in Table 1.

¥Data corrected using published correction values from reference Thurnham et al. ${ }^{(14)}$

$\S \mathrm{Hb}$ data corrected using values generated for the individual sexes. 
Table 5. Comparisons of corrected plasma retinol and ferritin concentrations of HIV-1-seropositive adults (this study) with other Kenyan data

\begin{tabular}{|c|c|c|c|c|}
\hline \multirow[b]{2}{*}{ Biomarker } & \multirow{2}{*}{$\frac{\text { This study }}{\text { Inflammation-corrected data }}$} & \multicolumn{3}{|c|}{ Comparison studies } \\
\hline & & Other Kenyan data & Description & Source (Reference) \\
\hline Plasma retinol & 1.33 & 1.29 & HIV negative, acute-phase & Baeten et al. ${ }^{(26)}$ \\
\hline Median quartiles & $0.94,1.63$ & $1.04,1.50$ & protein normal & \\
\hline $\begin{array}{l}\text { Plasma retinol } \\
\quad<0.7 \mu \mathrm{mol} / \mathrm{l}(\%)\end{array}$ & $13(n 22)$ & $20(n 81)$ & $\begin{array}{l}\text { Non-pregnant women at four } \\
\text { sites near Nanyuki and Nkuru }\end{array}$ & Mwaniki et al. ${ }^{(25)}$ \\
\hline $\begin{array}{l}\text { Plasma ferritin, median, } \\
\text { men }(\mu \mathrm{g} / \mathrm{l})\end{array}$ & 166 & $84(n 164)$ & $\begin{array}{l}\text { Geometric mean, twelve districts } \\
\text { in Central and Mid-western } \\
\text { Highlands }\end{array}$ & Mwaniki et al. ${ }^{(25)}$ \\
\hline $\begin{array}{l}\text { Plasma ferritin, median, } \\
\text { women }(\mu \mathrm{g} / \mathrm{l})\end{array}$ & 41 & $30(n 968)$ & & \\
\hline $\begin{array}{l}\text { Plasma ferritin, } \\
\text { women }<12 \mu \mathrm{g} / \mathrm{l}(\%)\end{array}$ & $19(n 20)$ & $28 \cdot 6(n 276)$ & $\begin{array}{l}\text { Data from twelve districts in } \\
\text { Central and Mid-western } \\
\text { Highlands }\end{array}$ & Mwaniki et al. ${ }^{(25)}$ \\
\hline
\end{tabular}

In this paper, we assume that the nutritional status of the apparently-healthy individuals who have raised APP and no clinical evidence of disease when the blood is taken, should be the same as those adults in the same community with normal acute phase status. That is, the differences in nutritional biomarkers between persons without and those with raised APP is due to the inflammatory state and not altered nutritional status. Thus in the case of vitamin A, if abnormal vitamin A status, i.e. low concentrations of plasma retinol, accompanies raised APP in the HIV+ adults, we have assumed the biochemical abnormalities are similar to those following surgery ${ }^{(2)}$, or found in malaria ${ }^{(3)}$, shigella dysentery $^{(29)}$ or measles ${ }^{(30)}$. In all these examples plasma vitamin A concentrations reverted to the pre-infection state without vitamin A intervention when the trauma of disease or surgery was removed or disappeared. However, the HIV infection is a slow onset disease and as the disease progresses, nutritional status may deteriorate even in apparently-healthy, HIV+ people. Thus even after the effects of inflammation are removed, nutritional biomarkers may still be abnormal when compared with HIV- persons living in the same area. To investigate this point, we compared the use of correction factors generated for retinol from the data of the HIV+ adults with the effects of using the correction factors that were generated previously in mainly non-HIV + persons $^{(14)}$ and we compared the corrected results with those from HIV - persons living in the same area and found that both methods of correction produced very similar median plasma retinol concentrations. This suggested that inflammation caused by HIV in apparently-healthy persons had a very similar effect on plasma retinol concentrations to that produced by other diseases.

Thus, the importance of the method used in this paper is that it presents a way of using all biochemical data from apparently-healthy persons and reduces the interference from residual inflammation in the early phase of, or following an infection. Currently our principal support for this view is that the increase in median plasma retinol concentrations after correction was almost the same irrespective of whether we used (1) correction factors produced previously by a meta-analysis of groups comprising mainly HIV - infants or (2) correction factors generated from the data of the seropositive adults themselves. Thus although the two sources of correction factors were very different, their effect on plasma retinol concentrations was almost the same. Undoubtedly, it will be argued that AIDS is a progressive and chronic disease and evidence suggests that as the disease progresses, seropositive persons become more and more malnourished. However, the evidence of malnutrition in patients with HIV is frequently obtained by methods which do not distinguish between biochemical abnormalities caused by malnutrition and those caused by the inflammation. In the introduction we highlighted the inhibitory effect of inflammation on the response to supplementary vitamin $\mathrm{A}^{(15)}$. Likewise a recent Cochrane review found little evidence of improvement in nutritional status of HIV+ persons following nutritional supplements ${ }^{(31)}$ and we suggest this is because the influence of inflammation on nutritional biomarkers has been overlooked.

However, if we examine more closely the suggestion that because HIV is a progressive disease, there will be elevated requirements for nutrients like vitamin $\mathrm{A}$ and, as the disease progresses, the risk or extent of vitamin A deficiency will increase. Thus those with the highest viral loads or lowest CD4 counts should be at greater risk of vitamin A deficiency than those persons whose inflammatory state is due to a more acute, self-limiting condition such as respiratory disease or diarrhoea. Table 3 confirms that those seropositive adults with raised APP had higher viral loads and lower CD4 counts and it is certainly true that the more severe the disease, the greater will be the inflammation produced and the greater the effect on nutrition biomarkers. However, in this study we are not trying to adjust the data for severity of disease but rather for the milder effects of sub-clinical inflammation. The adults in this study were not clinically unwell when the blood was taken. The distribution of subjects in Table 3 suggests that approximately half of the adults were recovering from sickness (groups 3 and 4, early and late convalescence), approximately $10 \%$ may have been incubating some illness (group 2) while $40 \%$ were well (or had not recently been ill; reference group). The correction procedure adjusts the median values of those groups with raised APP to those of the reference group. If vitamin A status was poorer in HIV+-apparently-healthy people than in those without HIV as might be inferred by a report from Kenya on retinol-binding protein metabolism ${ }^{(26)}$, retinol concentrations in the reference groups would be expected to be more abnormal in those with 
HIV. In fact the median retinol concentration in the reference group in this study $(1.33 \mu \mathrm{mol} / \mathrm{l})$ is almost the same as that reported by Baeten et al. ${ }^{(26)}(1.29 \mu \mathrm{mol} / \mathrm{l})$ for HIV - , APPnegative Kenyan women. If there is no difference in the median biomarkers concentrations in the reference groups, then poorer vitamin A status should be evident in those with HIV + and inflammation and the correction factors would need to be greater to adjust their data than those for people with acute, self-limiting infections. The correction factors from the two convalescent groups of HIV+ subjects are slightly higher than those from the meta-analysis but overall correction of plasma retinol by either method produced similar results, suggesting that in apparently-healthy persons with subclinical inflammation, correction factors for the different acute phase groups will be very similar irrespective of the nature of disease. It would obviously have been an advantage to have recruited HIV - adults from the same area to better interpret these data, but biomarker interpretation was not the primary objective of this feeding study.

Interference with nutritional biomarkers by inflammation is primarily from two sources, dietary intake and metabolism. Plasma retinol is depressed ${ }^{(32,33)}$ and plasma ferritin concentrations ${ }^{(5)}$ increase through the action of cytokines while carotenoids are more probably influenced by a depression in appetite. The degree of depression in plasma carotenoid concentrations probably depends on the proximity of the infection. The inverse associations between plasma carotenoid concentrations and the APP, especially AGP, suggests that previous infection depressed dietary intake. However, there is also evidence that the production of reactive oxygen species by stimulated polymorphonuclear leucocytes can oxidatively remove carotenoids from plasma ${ }^{(34)}$. Other workers have also reported inverse relationships between plasma carotenoid and CRP concentrations in apparently-healthy American adults $^{(6,7)}$ and it would seem prudent, irrespective of the causes of carotenoid depression, that that workers using plasma carotenoids as markers of fruit and vegetable intakes should be mindful of the influence of inflammation.

It is interesting that plasma $\alpha$ - or $\gamma$-tocopherol concentrations were not influenced by inflammation. If carotenoids are sensitive to oxidative damage and they, like the tocopherols, are transported in plasma by the lipoproteins, then the tocopherols should also be exposed to the same oxidative attack. However, there is no known mechanism to repair oxidised carotenoids whereas several reductants such as vitamin $\mathrm{C}$, glutathione and ubiquinone ${ }^{(35)}$ as well as the hepatic $\alpha$-tocopherol transfer protein ${ }^{(36)}$, may prevent a fall in plasma concentrations of $\alpha$-tocopherol although not all these factors can influence $\gamma$-tocopherol.

$\mathrm{Fe}$ deficiency in the developing world is often of equal importance to vitamin A deficiency. In the absence of inflammation, plasma ferritin concentrations are a good measure of Fe stores but unfortunately infection increases plasma ferritin, conceals the true level of Fe stores in a population and at the same time contributes to the level of anaemia (i.e. low plasma $\mathrm{Hb}$ ) by making $\mathrm{Fe}$ unavailable for the synthesis of new erythrocytes. Table 3 shows that plasma ferritin concentrations were more than five (women) and six (men) times higher in the groups in which both CRP and AGP were elevated than in the reference group. However corrected values from these data were more comparable with those reported for the community (Table 5) and increased the detection of women with low Fe stores almost two fold. Wieringa et al. ${ }^{(37)}$ also showed the importance of correcting plasma ferritin concentrations for inflammation since in the absence of raised APP, the prevalence of $\mathrm{Fe}$ deficiency in Indonesian infants was $26 \%$ whereas it appeared to be only $3-10 \%$ in those groups with raised APP. It is also of interest to note that in spite of the very large differences in ferritin concentrations between the Kenyan men and women, the correction factors were approximately the same for the respective groups. This suggests that in the presence of inflammation, the increase in ferritin is proportional to the pre-inflammation ferritin concentration in the different groups. Whether these relationships will apply to the very much smaller concentrations of ferritin in infants and children needs to be determined.

$\mathrm{Hb}$ was less strongly associated with the inflammatory APP than ferritin, the carotenoids or retinol. $\mathrm{Hb}$ concentrations showed very little difference between the three groups with raised APP in comparison to the reference group (Table 3). Friis et al. ${ }^{(38)}$ previously noted a drop of only $12.9 \mathrm{~g} / \mathrm{l}$ in the mean $\mathrm{Hb}$ associated with HIV seropositivity in pregnant Zimbabwean women. In this study the difference between median $\mathrm{Hb}$ concentrations of those groups without and with inflammation varied from 5 to $9 \mathrm{~g} / \mathrm{l}$. The correction for current inflammation only increased the median $\mathrm{Hb}$ concentration in both sexes combined by $5 \mathrm{~g} / \mathrm{l}$ and had very little effect on the numbers of cases of anaemia. The lack of effect of correcting $\mathrm{Hb}$ for inflammation is not surprising as the fall in $\mathrm{Hb}$ concentration is probably slow (days or weeks), depending as it does on both the availability of Fe and erythrocyte turnover. In contrast changes in APP status reduce retinol ${ }^{(2)}$ and increase ferritin ${ }^{(5)}$ in the first few hours following infection.

In conclusion, the calculated correction factors increase (or reduce) the medians of the whole group to that of the 'healthy' or reference group and thereby remove the influence of current inflammation. We suggest that identifying the group with no raised APP, or using the correction factors to remove the influence of inflammation from the whole data set, improves the measurement of true nutritional status of apparently-healthy persons in a specific community. Unfortunately, not all surveys will produce a reference group of sufficient size to calculate reliable corrections factors ${ }^{(14)}$. To meet this challenge, a meta-analysis as done for vitamin A will be needed also for ferritin and any other nutritional biomarkers where inflammation is shown to have major effects.

\section{Acknowledgements}

We thank UNICEF and the Dutch Government for providing funds to do the work in Kenya under project number SSA/ KENB/2002/00002302-03.

We thank Mrs Lilian Selenje, Programme Officer (Micronutrients) for UNICEF-ESARO for help with administration and Miss Faith Mugai, Mr Joseph Njoroge, Mr James Muthotho (Nakuru) and Dr Macharia Githigia (Nanyuki) for help in the field; Mr Elijah Kiarie (Nakuru) and Miss Margaret Ndegwa (Nanyuki) who prepared plasma and measured $\mathrm{Hb}$ and ESR and Mr Peter Waithaka and Mr Ronald Njagi for ferritin analyses. Also to thank are Dr Solomon Mpoke and $\mathrm{Mr}$ Kiellen Wafula from the Centre for Biotechnology and 
Research Development, KEMRI for CD4, CD8 and cytokine analyses and Professor H. Friis for measurements of viral load.

Contributions of authors

D. I. T. assisted in the preparation of the proposals for the study, assisted with the laboratory work in Northern Ireland and initiated the writing of this manuscript.

A. S. W. M. initiated the research, prepared the proposals and sought funds from UNICEF. She also managed the field work and laboratory work and prepared the report for UNICEF. D. L. M. assisted in the writing of the proposal, seeking funds from UNICEF, hiring staff, managing funds and solving problems. E. M. assisted in the writing of the proposal, computing the numbers needed for the study and analyses for the final report.

F. A. managed the work in the main field centre, interviewed subjects, collected food consumption data and assisted with data analysis. A. de W. assisted with the writing of the proposal, in the procurement of micronutrients and food supplies for the intervention part of the proposal and in seeking funds from UNICEF; A. de W. was, and still is, employed by UNICEF but has no conflicts of interest.

All authors assisted in the writing of the paper and have seen the final draft. None of the authors have any conflicts of interest in the writing and publication of this study.

\section{References}

1. Thurnham DI (1997) Impact of disease on markers of micronutrient status. Proc Nutr Soc 56, 421-431.

2. Louw JA, Werbeck A, Louw MEJ, Kotze TJvW, Cooper R \& Labadarios D (1992) Blood vitamin concentrations during the acute-phase response. Critical Care Med 20, 934-941.

3. Thurnham DI \& Singkamani R (1991) The acute phase response and vitamin A status in malaria. Trans $R$ Soc Trop Med Hyg $\mathbf{8 5}$, 194-199.

4. Beisel WR (1976) Trace elements in infectious processes. Med Clin North Am 60, 831-849.

5. Feelders RA, Vreugdenhil G, Eggermont AMM, Kuiper-Kramer PA, van Eijk HG \& Swaak AJG (1998) Regulation of iron metabolism in the acute-phase response: interferon- $\gamma$ and tumor necrosis factor- $\alpha$ induce hypoferraemia, ferritin production and a decrease in circulating transferrin receptors in cancer patients. Eur J Clin Invest 28, 520-527.

6. Kritchevsky SB, Bush AJ, Pahor M \& Gross MD (2000) Serum carotenoids and markers of inflammation in non-smokers. Am J Epidemiol 152, 1065-1071.

7. Erlinger TP, Guallar E, Miller ER, Stolzenberg-Solomon R \& Appel LJ (2001) Relationship between systemic markers of inflammation and serum $\beta$-carotene levels. Arch Intern Med 161, 1903-1908.

8. Galloway P, McMillan DC \& Sattar N (2000) Effect of the inflammatory response on trace element and vitamin status. Ann Clin Biochem 37, 289-297.

9. Bates CJ, Pentieva KD, Prentice A, Mansoor MA \& Finch S (1999) Plasma pyridoxal phosphate and pyridoxic acid and their relationship to plasma homocysteine in a representative sample of British men and women aged 65 years and over. Br J Nutr 81, 191-201.

10. Fleck A \& Myers MA (1985) Diagnostic and prognostic significance of acute phase proteins. In The Acute Phase Response to Injury and Infection, pp. 249-271 [AH Gordonand and A Koj, editors]. Amsterdam: Elsevier Scientific Publishers.
11. Calvin J, Neale G, Fotherby KJ \& Price CP (1988) The relative merits of acute phase proteins in the recognition of inflammatory conditions. Ann Clin Biochem 25, 60-66.

12. Thompson D, Milford-Ward A \& Whicher JT (1992) The value of acute phase protein measurements in clinical practice. Ann Clin Biochem 29, 123-131.

13. Stuart J \& Whicher JT (1988) Tests for detecting and monitoring the acute phase response. Arch Dis Child 63, 115-117.

14. Thurnham DI, McCabe GP, Northrop-Clewes CA \& Nestel P (2003) Effect of subclinical infection on plasma retinol concentrations and assessment of prevalence of vitamin A deficiency: meta-analysis. Lancet 362, 2052-2058.

15. Baeten JM, McClelland RS, Richardson BA, et al. (2002) Vitamin A deficiency and the acute phase response among HIV-1infected and -uninfected women in Kenya. J Acquir Immune Defic Syndr 31, 243-249.

16. Mburu ASW, Mwaniki DL, Thurnham DI, Selenje L, de Wagt A, Muniu EM, Friis H \& Krarup HB (2004) Effects of multimicronutrient supplements and food aid rations on the nutritional status and health of HIV+ adults (MINIFAR) (Report to UNICEF July 2004), pp. 1-209. Nairobi, Kenya: CPHRKEMRI.

17. Thurnham DI, Mburu ASW, Mwaniki DL \& de Wagt A (2005) Micronutrients in childhood and the influence of subclinical inflammation. Proc Nutr Soc 64, 502-509.

18. Krarup HB, Drewes AM \& Madsen PH (1998) A quantitative HCV-PCR test for routine diagnositics. Scand J Clin Lab Invest 58, 415-422.

19. Thurnham DI, Smith E \& Flora PS (1988) Concurrent liquidchromatographic assay of retinol, $\alpha$-tocopherol, $\beta$-carotene, $\alpha$-carotene, lycopene and $\beta$-cryptoxanthin in plasma with tocopherol acetate as internal standard. Clin Chem 34, 377-381.

20. Thurnham DI, Northrop-Clewes CA, Paracha PI \& McLoone UJ (1997) The possible significance of parallel changes in plasma lutein and retinol in Pakistani infants during the summer season. Br J Nutr 78, 775-784.

21. Sommer A \& Davidson FR (2002) Assessment of control and vitamin A deficiency: the Annecy accords. J Nutr 132, 2845S-2851S.

22. UNICEF, UNU \& WHO (2001) Iron Deficiency Anaemia. Assessment, Prevention and Control. A Guide for Programme Managers, pp. 1-114. WHO/NHD/01.3. Geneva, Switzerland: World Health Organization.

23. Worwood M (1982) Ferritin in human tissues and serum. Clin Haematol 11, 275-307.

24. Thurnham DI, Davies JA, Crump BJ, Situnayake RD \& Davis M (1986) The use of different lipids to express serum tocopherol:lipid ratios for the measurement of vitamin E status. Ann Clin Biochem 23, 514-520.

25. Mwaniki DL, Omwega AM, Minui EM, Mutunga JN, Akelola R, Shako BR, Gotink MH \& Pertet AM (2001) Anaemia and status of iron, vitamin A and zinc in Kenya. The 1999 National Survey Report. pp. 1-221. Nairobi, Ministry of Health.

26. Baeten JM, Wener MH, Bankson DD, Lavreys L, Richardson BA, Mandaliya K, Bwayo JJ \& McClelland RS (2006) HIV-1 infection alters the retinol-binding protein:transthyretin ratio even in the absence of the acute phase response. J Nutr 136, $1624-1629$

27. Gieng SH \& Rosales FJ (2006) Plasma alpha1-acid glycoprotein can be used to adjust inflammation-induced hyporetinolemia in vitamin A-sufficient, but not vitamin A-deficient or -supplemented rats. J Nutr 136, 1904-1909.

28. Beard JL, Murray-Kolb LE, Rosales FJ, Solomons NW \& Angelilli ML (2006) Interpretation of serum ferritin concentrations as indicators of total-body iron stores in survey populations: the role of biomarkers for the acute phase response. Am J Clin Nutr 84, 1498-1505. 
29. Mitra AK, Alvarez JO, Wahed MA, Fuchs GJ \& Stephensen CB (1998) Predictors of serum retinol in children with shigellosis. Am J Clin Nutr 68, 1088-1094.

30. Reddy V, Bhaskaram P, Raghuramulu N, Milton RC, Rao V, Madhusudan J \& Radha Krishna KV (1986) Relationship between measles, malnutrition, and blindness: a prospective study in Indian children. Am J Clin Nutr 44, 924-930.

31. Irlam JH, Visser ME, Rollins N \& Siegfried N (2005) Micronutrient supplementation in children and adults with HIV infection. Cochrane Database Syst Rev 4 CD 003650.

32. Rosales FJ, Ritter SJ, Zolfaghari R, Smith JE \& Ross AC (1996) Effects of acute inflammation on plasma retinol, retinol-binding protein, and its messenger RNA in the liver and kidneys of vitamin A sufficient rats. J Lipid Res 37, 962-971.

33. Tabone MD, Muanza K, Lyagoubi M, Jardel C, Pied S \& Amedee-Manesme O (1992) The role of interleukin-6 in vitamin A deficiency during Plasmodium falciparum malaria and possible consequences for vitamin A supplementation. Immunol 75, 553-554.

34. Sommerburg O, Langhans C-D, Arnhold J, Leichsenring M, Salerno C, Crifo C, Hoffman GF, Debatin K-M \& Siems WG (2003) $\beta$-Carotene cleavage products after oxidation mediated by hypochlorous acid - A model for neutrophil-derived degradation. Free Rad Biol Med 35, 1480-1490.

35. Chaudiere J \& Ferrari-Iliou R (1999) Intracellular antioxidants from chemical to biochemical mechanisms. Food Chem Toxicol 37, 949-962.

36. Traber MG, Ramakrishanan R \& Kayden HJ (1994) Human plasma vitamin $\mathrm{E}$ kinetics demonstrate rapid recycling of plasma RRR-alpha-tocopherol. Proc Natl Acad Sci U S A 91, 10005-10008.

37. Wieringa FT, Dijkhuizen MA, West CE, Northrop-Clewes CA \& Muhilal (2002) Estimation of the effect of the acute phase response on indicators of micronutrient status in Indonesian infants. $J$ Nutr 132, 3061-3066.

38. Friis H, Gomo E, Koestel P, Ndhlovu P, Nyazema N, Krarup H \& Michaelsen KF (2001) HIV and other predictors of serum folate, serum ferritin, and hemoglobin in pregnancy: a cross-sectional study in Zimbabwe. Am J Clin Nutr 73, 1066-1073.

39. Mehendale SM, Shepherd ME, Brookmeyer RS, et al. (2001) Low carotenoid concentrations and the risk of HIV seroconversion in Pune, India. J Acquir Immune Defic Syndr 26, 352-359.

40. Dacie JV \& Lewis SM (1995) Practical Haematology. London: Churchill Livingston. 